\title{
TRIMETHOPRIM-SULFAMETHOXAZOLE RESISTANCE AND FOSFOMYCIN SUSCEPTIBILITY RATES IN UNCOMPLICATED URINARY TRACT INFECTIONS: TIME TO CHANGE THE ANTIMICROBIAL PREFERENCES
}

\author{
Ozlem Guneysel ${ }^{1}$, Enes Suman ${ }^{2}$ and Tuba Cimilli Ozturk ${ }^{3}$ \\ ${ }^{1}$ Lutfi Kirdar Kartal Education and Research Hospital, Emergency Medicine Clinic; ${ }^{2}$ Recep Tayyip Erdogan \\ University Education and Research Hospital, Emergency Medicine Clinic; ${ }^{3}$ Fatih Sultan Mehmet Education and \\ Research Hospital, Emergency Medicine Clinic, Istanbul, Turkey
}

\begin{abstract}
SUMMARY - Urinary tract infections (UTIs) are among the most common bacterial infections in adult population. They are prevalent in all age groups both in women and men. Also, UTIs are the most frequent indication for empirical antibiotic treatment in emergency department. The aim of this study was to determine the antibiotic resistance rates in the treatment of uncomplicated UTIs. Adult patients admitted to emergency department with uncomplicated UTIs were included in this cross-sectional study. Mid-stream urine samples were obtained under sterile conditions and cultured quantitatively. After 24 hours, the samples showing $10^{5}$ colony forming unit per milliliter $(\mathrm{CFU} / \mathrm{mL})$ were tested for antibiotic susceptibility. Resistance to fosfomycin-trometamol (FT), amoxicillin-clavulanic acid (AC), ciprofloxacin (CIP), trimethoprim-sulfamethoxazole (TMP$\mathrm{SMX}$ ) and cefpodoxime (CEF) was tested by Kirby-Bauer disc diffusion system. Escherichia (E.) coli accounted for the vast majority (93.4\%) of the organisms isolated in the study. Among the $E$. coli positive patients, resistance to TMP-SMX was the most common antibiotic resistance. The $E$. coli species detected in our study group were least resistant to FT (2.4\%). The resistance rates, especially to $\mathrm{CEF}, \mathrm{AC}$ and CIP, were significantly higher in patients over 50 years of age. In conclusion, in the treatment of uncomplicated UTIs, TMP-SMX should be excluded from empirical treatment, while fosfomycin could be a viable option in all age groups.
\end{abstract}

Key words: Urinary tract infections - drug therapy; Drug resistance, microbial; Fosfomycin - therapeutic use; Trimethoprim, sulfamethoxazole drug combination - therapeutic use; Emergencies

\section{Introduction}

Urinary tract infections (UTIs) are among the most common bacterial infections in adult population. In the United States, there are nearly 10 million outpatient visits for UTIs annually. Almost one-fifth of these visits are to hospital emergency departments.

Correspondence to: Assoc. Prof. Ozlem Guneysel, MD, Dr Lutfi Kirdar Kartal Education and Research Hospital, Emergency Medicine Clinic, Semsi Denizer C Cevizli Mevki, Kartal-Istanbul, Turkey

E-mail: guneysel@gmail.com

Received July 8, 2014, accepted December 15, 2015
UTIs are also the most common primary diagnosis in women presenting to emergency departments ${ }^{1}$. Acute cystitis and pyelonephritis are the most frequent indications for empirical antibiotic treatment without urine culture, especially in emergency department ${ }^{2}$. However, the success of infection treatment is directly related to rational prescription of antibiotics. Due to the resistance problem, inappropriate use of antibiotics leads universally to high medical expenses. In 2012, the study by Mollahaliloglu et al. demonstrated that the most common diagnosis in prescriptions containing antibiotics was "urinary tract infection". When calculating the cost of prescriptions, they 
observed that antibiotics accounted for $50.7 \%$ of the total cost $^{3}$.

The responsible bacteria in most UTIs are the Enterobacteriaceae species. Escherichia (E.) coli is the most frequently isolated bacterium with a prevalence rate of 75\%-95\%. Proteus mirabilis, Klebsiella pneumoniae and Staphylococcus saprophyticus are other frequently observed species in young and healthy women (5\%$15 \%)^{2,4}$. In adult male patients, $E$. coli is also the most frequently observed causative organism. Proteus, Klebsiella, Serratia, Pseudomonas and other Enterococcus species are also isolated in urine cultures, especially in older male patients 5 .

Urinary tract infections are usually described under the headings of complicated and uncomplicated infections because of the need for different treatment strategies. Uncomplicated UTIs are infections of the urinary system in patients without any neurological, functional or anatomical abnormalities and are usually observed in young healthy and non-pregnant women. The risk factors for complicated UTIs include male sex, advanced age, hospitalization, pregnancy, urinary catheter, residual urine in the bladder, functional or anatomical abnormalities of urinary tract, immunosuppression, diabetes mellitus, symptoms lasting for more than seven days, and inappropriate antibiotic treatment ${ }^{6}$. UTIs are very rarely observed in men aged 15-50. However, if pyelonephritis is diagnosed in this age group, it almost always presents a risk factor. Another important thing is that there is usually recurrence of the infection and undetected resistance to antibiotics in most complicated $\mathrm{UTI}^{7}{ }^{7,8}$. Empirical prescription of inappropriate antibiotics is probably the main reason for the increased rates of antimicrobial resistance.

The Infectious Disease Society of America and the European Society for Microbiology and Infectious Diseases Committee have published the latest recommendations for the treatment of uncomplicated UTIs. It is emphasized in the guideline that the recommendations are limited, and must be updated according to the regional antimicrobial resistance rates and patterns. According to the guideline, the first-line treatment options for uncomplicated UTIs include nitrofurantoin monohydrate, trimethoprim sulfamethoxazole, fosfomycin trometamol, and pivmecillinam. It is advised that fluoroquinolones and $\beta$-lactam agents should be reserved for alternative treatments. In case of uncomplicated pyelonephritis, ciprofloxacin, ceftriaxone or trimethoprim sulfamethoxazole should be the first choice ${ }^{2}$.

The aim of this study was to identify causative pathogens of uncomplicated UTIs in adult patients admitted to our emergency department and to provide an updated information about the antimicrobial resistance profile with the most frequently prescribed empirical antibiotics (fosfomycin-trometamol (FT), amoxicillin-clavulanate (AC), ciprofloxacin (CIP), trimethoprim-sulfamethoxazole (TMP-SMX) and cefpodoxime (CEF)) in the Istanbul region.

\section{Materials and Methods}

The study was conducted prospectively in a tertiary inner city hospital over a period from April 15 to September 15, 2012, after approval of the Hospital Ethics and Research Committee. Patients over 16 years of age admitted to emergency department with the diagnosis of uncomplicated UTI were enrolled in the study.

Patients with septic shock, pyelonephritis, anatomical or functional anomaly in the urinary tract, malignancy, and immunosuppression were not included in the study. Histories of UTIs or urinary catheterization in the last one month and antibiotic usage for any reason in the last seven days were the other exclusion criteria.

Midstream clean catch urine samples were cultured within one hour quantitatively in 5\% Sheep Blood Agar and Eosin Methylene Blue (EMB) plates (bioMerieux, France) with a standard wire loop. Inoculated agar plates were incubated at $37^{\circ} \mathrm{C}$ and read after 24 hours. Presence of at least $10^{5}$ colony forming units per milliliter (CFU/mL) single bacterium colonies were accepted as significant bacteriuria. Identification of the bacteria was performed by standard conventional methods. If needed, they were biochemically tested with API system (bioMerieux, France). API $20 \mathrm{E}$ was used for oxidase-negative, gram-negative bacilli and API20NE was used for oxidase-positive, gram-negative bacilli.

Antibiotic susceptibilities were tested with KirbyBauer disc diffusion system and the results were interpreted according to the methods described in the 
Clinical and Laboratory Standards Institute (CLSI) documents 9 . Mueller Hinton Agar (bioMerieux, France), and discs containing $200 \mathrm{mcg}$ FT, 20/10 AC, $5 \mathrm{mcg}$ CIP, $1.25 / 23.75 \mathrm{mcg}$ TMX-SMX and $10 \mathrm{mcg}$ CEF (Oxoid, UK) were used for testing antibiotic susceptibility, respectively. For the purpose of quality control, E. coli ATCC 25922 was used as the standard strain in all assays. In the study, the susceptibility level of the isolated microorganisms against the tested antibiotics was determined as 'susceptible', 'intermediate' or 'resistant' according to the susceptibility zone diameter'.

\section{Statistical analysis}

The SPSS 20.0 program was used on data analysis. In descriptive statistics, data on the frequency, rate, mean and standard deviation were used. The distribution of variables was checked by Kolmogorov-Smirnov test. Independent-samples $t$ test was used for quantitative analysis of the data. The $\chi^{2}$-test was used in the analysis of qualitative data. Fisher test was used when the $\chi^{2}$-test conditions could not be reached.

\section{Results}

Urine culture samples of patients admitted to emergency medicine department with the diagnosis of uncomplicated UTI were evaluated. Five hundred urine cultures were analyzed during the study period. Three hundred and fifty-five (71\%) samples were obtained from female and the rest (29\%) were obtained from male patients. The distribution of patients according to age is shown in Table 1 . Most of the patients were aged 21-40 (54.4\%) (Table 1).

Table 1. Demographic characteristics

\begin{tabular}{|c|c|c|}
\hline & $\mathrm{n}$ & $\%$ \\
\hline $\begin{array}{c}\text { Gender } \\
\text { female } \\
\text { male }\end{array}$ & 355 & 71 \\
\hline Age (yrs) & 145 & 29 \\
$16-20$ & 43 & \\
$21-30$ & 155 & 8.6 \\
$31-40$ & 112 & 31.0 \\
$41-50$ & 63 & 22.4 \\
$51-60$ & 52 & 12.6 \\
$61<$ & 75 & 10.4 \\
\hline
\end{tabular}

Table 2. Age and gender distribution of urine cultures

\begin{tabular}{|c|cc|cc|c|}
\hline & \multicolumn{4}{|c|}{ Urine culture } & \multirow{2}{*}{ Negative } \\
& \multicolumn{2}{|c|}{ Nositive } & $\mathrm{p}$ \\
\hline Gender & $\mathrm{n}$ & $\%$ & $\mathrm{n}$ & $\%$ & \\
\hline Female & 251 & 67.3 & 73 & 80.2 & \multirow{2}{*}{0.016} \\
Male & 122 & 32.7 & 18 & 19.8 & \\
\hline Age & $39.9 \pm 17.2$ & $39.7 \pm 16.2$ & 0.862 \\
(mean \pm SD) & & & & & \\
\hline Age & & & & & \\
distribution & 33 & 8.8 & 7 & 7.7 & \\
$16-20$ & 116 & 31.1 & 27 & 29.7 & \\
$21-30$ & 84 & 22.5 & 24 & 26.4 & 0.980 \\
$31-40$ & 47 & 12.6 & 12 & 13.2 & \\
$41-50$ & 36 & 9.7 & 8 & 8.8 & \\
$51-60$ & 57 & 15.3 & 13 & 14.3 & \\
$60<$ & & & & \\
\hline
\end{tabular}

${ }^{*} \chi^{2}$ distribution/independent samples t-test

The urine culture results were negative in 373 (74.6\%) patients. Thirty-six (7.2\%) samples were considered contaminated and excluded from the study. Significant growth of $10^{5} \mathrm{CFU} / \mathrm{mL}$ urine was recorded in 91 (18.2\%) samples. Seventy-three isolates, representing $80.2 \%$ of the total isolates were recovered from female patients, while 18 (19.8\%) were isolated from male patients (Table 2). The most common uropathogen isolated from the cultures in the study group was E. coli (93.4\%). Proteus spp. constituted $4.4 \%$ of the pathogens, and the rest of the isolates were Klebsiella spp. (2.2\%) (Table 3).

Bacterial growth in urine samples from female patients was significantly higher as compared with urine samples of male patients $(p=0.002)$. The mean age of the culture negative and culture positive patients was $39.9 \pm 17.2$ and $39.7 \pm 16.2$, respectively. The age distribution according to bacterial growth did not show statistically significant difference ( $p>0.05)$ (Table 2).

Antibiotic susceptibility studies of the isolated pathogens are shown in Table 4 . The highest resistance rate was observed to TMP-SMX (36.3\%). The pathogens isolated from the study urine samples were least resistant to FT (2.2\%).

Comparison of antibiotic resistance rates between male and female patients revealed resistance to FT, $\mathrm{CEF}$ and CIF to be significantly higher in male patients, with the calculated p values of $0.004,0.016$ and 
Table 3. Distribution of isolates according to gender and age groups

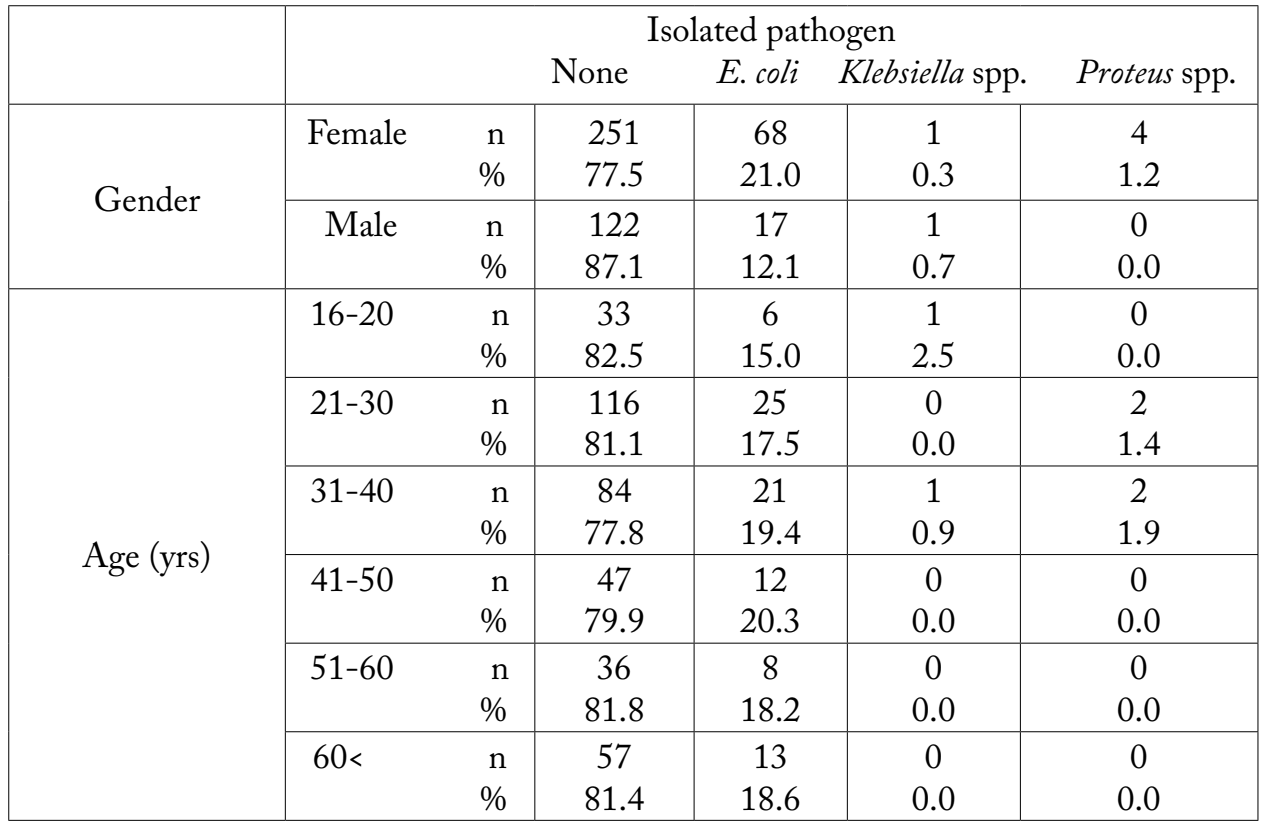

Table 4. Antibiotic resistance and susceptibility rates among female and male patients

\begin{tabular}{|c|c|c|c|c|c|c|}
\hline & & \multicolumn{2}{|c|}{ Female } & \multicolumn{2}{|c|}{ Male } & \multirow{2}{*}{$\mathrm{p}$} \\
\hline & & $\mathrm{n}$ & $\%$ & $n$ & $\%$ & \\
\hline \multirow{2}{*}{ Fosfomycin } & Susceptible & 73 & 100 & 16 & 88.9 & \multirow{2}{*}{0.0004} \\
\hline & Resistant & 0 & 0 & 2 & 11.1 & \\
\hline \multirow{2}{*}{ Cefpodoxime } & Susceptible & 60 & 82.2 & 10 & 55.6 & \multirow{2}{*}{0.016} \\
\hline & Resistant & 13 & 17.8 & 8 & 44.4 & \\
\hline \multirow{2}{*}{$\begin{array}{l}\text { Amoxicillin/ } \\
\text { clavulanic acid }\end{array}$} & Susceptible & 63 & 86.3 & 13 & 72.2 & \multirow{2}{*}{0.149} \\
\hline & Resistant & 10 & 13.7 & 5 & 27.8 & \\
\hline \multirow{2}{*}{$\begin{array}{l}\text { Trimethoprim/ } \\
\text { sulfamethoxazole }\end{array}$} & Susceptible & 49 & 67.1 & 9 & 50.0 & \multirow{2}{*}{0.176} \\
\hline & Resistant & 24 & 32.9 & 9 & 50.0 & \\
\hline \multirow{2}{*}{ Ciprofloxacin } & Susceptible & 58 & 79.5 & 10 & 55.6 & \multirow{2}{*}{0.037} \\
\hline & Resistant & 15 & 20.5 & 8 & 44.4 & \\
\hline
\end{tabular}

0.037, respectively. Resistance rates to TMP-SMX and AC did not show any statistically significant gender difference (Table 4).

Resistance rates to CEF, CIP and $\mathrm{AC}$ were significantly higher in patients older than 50 as compared with those younger than 50 . However, there was no statistically significant age difference in the resistance rates to FT and TMP-SMX (Table 5).

Among the female patient urine samples, $68 \mathrm{E}$. coli, 4 Proteus spp. and 1 Klebsiella spp. were isolated.
Table 6 shows antibiotic resistance patterns of the uropathogens isolated from the samples of female patients. Of the $E$. coli strains cultured in female patient samples, $32.4 \%$ showed resistance to TMP-SMX. The $\mathrm{CIP}, \mathrm{CEF}$ and $\mathrm{AC}$ resistance rates in this group were $20.6 \%, 17.6 \%$ and $13.2 \%$, respectively. $E$ coli strains isolated from the samples of female patients were not resistant to $\mathrm{FT}(0 \%)$.

Among the male patient urine samples, $17 \mathrm{E}$. coli strains and 1 Klebsiella spp. were isolated. Table 7 il- 
Table 5. Antibiotic susceptibility and resistance rates according to age groups

\begin{tabular}{|c|c|c|c|c|c|c|}
\hline & & \multicolumn{2}{|c|}{$<50$ years } & \multicolumn{2}{|c|}{50 years $\leq$} & \multirow[b]{2}{*}{ *p } \\
\hline & & $\mathrm{n}$ & $\%$ & $\mathrm{n}$ & $\%$ & \\
\hline \multirow{2}{*}{ Fosfomycin } & Susceptible & 69 & 98.6 & 20 & 95.2 & \multirow{2}{*}{0.410} \\
\hline & Resistant & 1 & 1.4 & 1 & 4.8 & \\
\hline \multirow{2}{*}{ Cefpodoxime } & Susceptible & 61 & 87.1 & 9 & 42.9 & \multirow{2}{*}{0.0} \\
\hline & Resistant & 9 & 12.9 & 12 & 57.1 & \\
\hline \multirow{2}{*}{$\begin{array}{l}\text { Amoxicillin/ } \\
\text { clavulanic acid }\end{array}$} & Susceptible & 64 & 91.4 & 12 & 57.1 & \multirow{2}{*}{0.0} \\
\hline & Resistant & 6 & 8.6 & 9 & 42.9 & \\
\hline \multirow{2}{*}{$\begin{array}{l}\text { Trimethoprim/ } \\
\text { sulfamethoxazole }\end{array}$} & Susceptible & 48 & 68.6 & 10 & 47.6 & \multirow{2}{*}{0.080} \\
\hline & Resistant & 22 & 31.4 & 11 & 52.4 & \\
\hline \multirow{2}{*}{ Ciprofloxacin } & Susceptible & 59 & 84.3 & 9 & 42.9 & \multirow{2}{*}{0.0} \\
\hline & Resistant & 11 & 15.7 & 12 & 57.1 & \\
\hline
\end{tabular}

* $\chi^{2}$-test/Fisher test

lustrates the antibiotic susceptibility studies of the uropathogens cultured in male patient samples. Resistance rates to TMP-SMX and CIP of E. coli strains cultured in male patient samples were the same (47.1\%). Resistance rates to AC and FT were $29.4 \%$ and $11.8 \%$, respectively.

The antibiotic resistance rates of the isolated pathogens in the culture positive patients are shown in $\mathrm{Ta}^{-}$ ble 8. Of the E. coli strains as the most common uropathogens isolated in the study samples, $35.3 \%$ were found to be resistant to TMP-SMX. The resistance rates to CIP, CEF, AC and FT were 25.9\%, 25.3\%, $16.5 \%$ and $2.4 \%$, respectively.

\section{Discussion}

Uncomplicated UTIs are generally thought of as UTIs occurring in otherwise healthy, young, female and sexually active but non-pregnant patients without an underlying defect in urinary anatomy or renal function ${ }^{10}$. Female gender is described as a primary risk factor for UTIs, while some authors even accepted all male UTIs as complicated ${ }^{2,5-7,10,11}$. In our study, women also constituted the majority of the study group (71.9\%); furthermore, $80.2 \%$ of the culture positive urine samples collected for the study were obtained from female patients. According to our re-

Table 6. Antibiotic resistance rates of pathogens isolated from female patient samples

\begin{tabular}{|c|c|c|c|c|c|c|c|}
\hline \multirow{3}{*}{\multicolumn{2}{|c|}{ Female patients }} & \multicolumn{6}{|c|}{ Pathogen growth } \\
\hline & & \multicolumn{2}{|c|}{ E. coli } & \multicolumn{2}{|c|}{ Klebsiella spp. } & \multicolumn{2}{|c|}{ Proteus spp. } \\
\hline & & $\mathrm{n}$ & $\%$ & $\mathrm{n}$ & $\%$ & $\mathrm{n}$ & $\%$ \\
\hline \multirow{2}{*}{ Fosfomycin } & Susceptible & 68 & 100 & 1 & 100 & 4 & 100 \\
\hline & Resistant & 0 & 0 & 0 & 0 & 0 & 0 \\
\hline \multirow{2}{*}{ Cefpodoxime } & Susceptible & 56 & 82.4 & 0 & 0 & 4 & 100 \\
\hline & Resistant & 12 & 17.6 & 1 & 100 & 0 & 0 \\
\hline \multirow{2}{*}{$\begin{array}{l}\text { Amoxicillin/ } \\
\text { clavulanic acid }\end{array}$} & Susceptible & 59 & 86.8 & 0 & 0 & 4 & 100 \\
\hline & Resistant & 9 & 13.2 & 1 & 100 & 0 & 0 \\
\hline \multirow{2}{*}{$\begin{array}{l}\text { Trimethoprim/ } \\
\text { sulfamethoxazole }\end{array}$} & Susceptible & 46 & 67.6 & 0 & 0 & 3 & 75 \\
\hline & Resistant & 22 & 32.4 & 1 & 100 & 1 & 25 \\
\hline \multirow{2}{*}{ Ciprofloxacin } & Susceptible & 54 & 79.4 & 0 & 0 & 4 & 100 \\
\hline & Resistant & 14 & 20.6 & 1 & 100 & 0 & 0 \\
\hline
\end{tabular}


Table 7. Antibiotic resistance rates of pathogens isolated from male patient samples

\begin{tabular}{|c|c|c|c|c|c|}
\hline \multirow{3}{*}{\multicolumn{2}{|c|}{ Male patients }} & \multicolumn{4}{|c|}{ Pathogen growth } \\
\hline & & \multicolumn{2}{|c|}{ E. coli } & \multicolumn{2}{|c|}{ Klebsiella spp. } \\
\hline & & $\mathrm{n}$ & $\%$ & $\mathrm{n}$ & $\%$ \\
\hline \multirow{2}{*}{ Fosfomycin } & Susceptible & 15 & 88.2 & 1 & 100 \\
\hline & Resistant & 2 & 11.8 & 0 & 0 \\
\hline \multirow{2}{*}{ Cefpodoxime } & Susceptible & 9 & 52.9 & 1 & 100 \\
\hline & Resistant & 8 & 47.1 & 0 & 0 \\
\hline \multirow{2}{*}{$\begin{array}{l}\text { Amoxicillin/ } \\
\text { clavulanic acid }\end{array}$} & Susceptible & 12 & 70.6 & 1 & 100 \\
\hline & Resistant & 5 & 29.4 & 0 & 0 \\
\hline \multirow{2}{*}{$\begin{array}{l}\text { Trimethoprim/ } \\
\text { sulfamethoxazole }\end{array}$} & Susceptible & 9 & 52.9 & 0 & 0 \\
\hline & Resistant & 8 & 47.1 & 1 & 100 \\
\hline \multirow{2}{*}{ Ciprofloxacin } & Susceptible & 9 & 52.9 & 1 & 100 \\
\hline & Resistant & 8 & 47.1 & 0 & 0 \\
\hline
\end{tabular}

sults, the overall antibiotic resistance rates observed in male patients were higher as compared to female patients. According to the recent guidelines for optimal treatment of uncomplicated UTIs, it is reasonable to prescribe empirical antibiotics. It is also emphasized that routine urine culture is not usually necessary for uncomplicated UTIs other than pyelonephritis. However, the most important thing is that local antibiotic resistance pattern should be updated periodically according to the isolated uropathogens.

We found that $E$. coli strains remained the predominant pathogen isolated in urine samples ${ }^{5-7,10}$.
However, the prevalence rates vary from $75 \%$ to $95 \%$ worldwide, as well as in the previously conducted studies in Turkey ${ }^{12-15}$. In our study, the prevalence of $E$. coli strains isolated from urine samples of the study group was $93.4 \%$. Although there are reports on the high resistance rates of uropathogens to TMP-SMX, it still takes place as a treatment option for UTIs. In many reports, the resistance rates range between $26 \%$ and $63 \%{ }^{12,16-20}$. However, it is advised that if local resistance rates exceed 20\%, fluoroquinolones should be used instead of TMP-SMX ${ }^{2,5,7}$. In our study, the overall resistance to TMP-SMX was $36.3 \%$. There-

Table 8. Antibiotic susceptibility studies of isolated uropathogens

\begin{tabular}{|c|c|c|c|c|c|c|c|}
\hline & & \multicolumn{6}{|c|}{ Pathogen growth } \\
\hline \multirow{2}{*}{\multicolumn{2}{|c|}{ All patients }} & \multicolumn{2}{|c|}{ E. coli } & \multicolumn{2}{|c|}{ Klebsiella spp. } & \multicolumn{2}{|c|}{ Proteus spp. } \\
\hline & & $\mathrm{n}$ & $\%$ & $\mathrm{n}$ & $\%$ & $\mathrm{n}$ & $\%$ \\
\hline \multirow{2}{*}{ Fosfomycin } & Susceptible & 83 & 97.6 & 2 & 100 & 4 & 100 \\
\hline & Resistant & 2 & 2.4 & 0 & 0 & 0 & 0 \\
\hline \multirow{2}{*}{ Cefpodoxime } & Susceptible & 65 & 76.5 & 1 & 50 & 4 & 100 \\
\hline & Resistant & 20 & 23.5 & 1 & 50 & 0 & 0 \\
\hline \multirow{2}{*}{$\begin{array}{l}\text { Amoxicillin/ } \\
\text { clavulanic acid }\end{array}$} & Susceptible & 71 & 83.5 & 1 & 50 & 4 & 100 \\
\hline & Resistant & 14 & 16.5 & 1 & 50 & 0 & 0 \\
\hline \multirow{2}{*}{$\begin{array}{c}\text { Trimethoprim/ } \\
\text { sulfamethoxazole }\end{array}$} & Susceptible & 55 & 64.7 & 0 & 0 & 3 & 75 \\
\hline & Resistant & 30 & 35.3 & 2 & 100 & 1 & 25 \\
\hline \multirow{2}{*}{ Ciprofloxacin } & Susceptible & 63 & 74.1 & 1 & 50 & 4 & 100 \\
\hline & Resistant & 22 & 25.9 & 1 & 50 & 0 & 0 \\
\hline
\end{tabular}


fore, it seems that TMP-SMX should not be the drug of choice for empirical UTI treatment in our region.

In recent years, fluoroquinolones have become more popular among physicians for the treatment of UTIs. Mollahaliloglu et al. report on the $46.4 \%$. rate of fluoroquinolone prescription for the diagnosis of UTIs. In their study, the most frequently prescribed quinolone was levofloxacin (23.2\%) ${ }^{3}$. Guneysel et al. also report that fluoroquinolones were the treatment of choice for UTIs. Ofloxacin was the most frequently used drug in their study ${ }^{17}$. Caterino et al. report that between 1996 and 2005, TMP-SMX prescription rates decreased gradually while the frequency of prescription of fluoroquinolones increased ${ }^{21}$. The antibiotic susceptibility studies showed progressively increasing resistance rates for quinolones in Turkey. For example, Aydin et al. ${ }^{22}$ found $1.6 \%$ resistance rate to CIP in 1996; however, in 1999, Sencan et al..$^{23}$ and in 2001 Sucu et al. ${ }^{24}$ reported on the resistance rates to CIP of $5 \%$ and $18 \%$, respectively. The studies conducted between 2000 and 2005 showed 16.8\%-39\% CIP resistance of $E$. coli strains isolated in UTIs ${ }^{14,25-27}$. According to our results, the CIP resistance rate was $25.9 \%$ in the study group. Therefore, routine prescription of CIP for uncomplicated UTIs cases appears to be questionable in all age groups.

It seems that advanced age is also an important parameter. We found that resistance rates, especially to $\mathrm{CEF}, \mathrm{AC}$ and CIP, were significantly higher among patients over 50 years compared to younger patients. The resistance rates of uropathogens to $\mathrm{CEF}, \mathrm{AC}$ and CIP were $57.1 \%, 42.9 \%$ and $57.1 \%$, respectively. Our results are consistent with literature data ${ }^{19,28,29}$. In our study, CEF, AC and CIP resistance rates in patients younger than 50 were $12.9 \%, 8.6 \%$ and $15.7 \%$, respectively. FT resistance was very low in both groups. It is reasonable to obtain urine culture routinely from patients over 50 years of age. According to our results, $\mathrm{CEF}, \mathrm{AC}, \mathrm{CIP}$ and FT can be prescribed empirically for patients younger than 50 years.

Because of the advantage of single-dose treatment, FT has recently become increasingly preferred by the physicians. The side effect profile is tolerable and patient compliance is generally better than with other drugs. Antibiotic susceptibility testing reports for FT are also promising worldwide. In the literature, resistance rates vary from $0 \%$ to $6.9 \% 0^{15,26,27,30-32}$. In our study, FT resistance was $2.2 \%$ in the study group and the resistance was higher in male patients (11\%). The pathogens cultured in the samples of our female patients were all susceptible to FT. According to our results, FT can be preferred for uncomplicated UTIs in males and females of all age groups.

Regional differences were also remarkable in the reports on antibiotic susceptibility testing from Turkey. Tasbakan et al. report on the resistance rates of E. coli strains of $39 \%, 11 \%$ and $43 \%$ to CIP, AC and TMP-SMX, respectively ${ }^{33}$. Ay et al. report on the resistance rates of $21 \%, 40 \%$ and $42 \%$ to CIP, AC and TMP-SMX, respectively ${ }^{34}$. In the study by Bingöl et al., E. coli strains showed $16.8 \%$ resistance to CIP and $35 \%$ resistance to TMP-SMX ${ }^{35}$. Our study was conducted in Istanbul, and $35.3 \%$ of the E. coli strains, which were the most common uropathogens isolated from the samples, were resistant to TMP-SMX. The resistance rates to CIP, CEF, AC and FT were 25.9\%, $25.3 \%, 16.5 \%$ and $2.4 \%$, respectively. Therefore, regional differences should also be taken in consideration when deciding on the choice of empirical antibiotics. Local microbiology laboratories should also report their surveillance data periodically.

\section{Conclusion}

Resistance rates, especially to CEF, AC and CIP, were significantly higher in patients older than 50. Therefore, it is reasonable to obtain routine urine culture from this group of patients. In the management of uncomplicated UTIs, TMP-SMX should be excluded from empirical treatment, while fosfomycin could be a viable option in all age groups.

\section{Acknowledgment}

Special thanks to Ertan Koc (İstatistik Akademi) for his valuable support in statistical data analysis.

\section{References}

1. Foxman B. Urinary tract infection syndromes: occurrence, recurrence, bacteriology, risk factors, and disease burden. Infect Dis Clin North Am. 2014;28(1):1-13. doi: 10.1016/j. idc.2013.09.003.

2. Gupta K, Hooton TM, Naber KG, Wullt B, Colgan R, et al. International clinical practice guidelines for the treatment of acute uncomplicated cystitis and pyelonephritis in women: a 
2010 update by the Infectious Diseases Society of America and the European Society for Microbiology and Infectious Diseases. Clin Infect Dis. 2011;52(5):e103-20. doi: 10.1093/ cid/ciq257.

3. Mollahaliloglu S, Alkan A, Dönertas B, Ozgulcu Ş, Dilmen U, Akici A. Tek enfeksiyon tanılı reçetelere hekimlerin yazdığ 1 antibiyotiklerin değerlendirilmesi. Marmara Pharm J. 2012;16:206-12. doi: 10.12991/201216400. (in Turkish)

4. Koeppen BM, Stanton BA. Renal Physiology, St. Louis, MO: Mosby. 2001.

5. Grabe M, Bjerklund-Johansen TE, Botto H, Wullt B, Çek $\mathrm{M}$, Naber KG, et al. Guidelines on urological infections. European Association of Urology 2011. Available at: http:// uroweb.org/wp-content/uploads/17_Urological-infections_ LR-II.pdf Access date: 18.11.2015

6. Topçu WA, Söyletir G, Doğanay M, editors. Enfeksiyon Hastalıkları ve Mikrobiyolojisi Sistemlere Göre Enfeksiyonlar 1: İdrar Yolu Enfeksiyonlar1. Nobel Tip Kitabevi, İstanbul 2008:1487-99. (in Turkish)

7. Sobel JD, Kaye D. Urinary tract infections. In: Mandell GL, Bennett JE, Dolin R, editors. Mandell, Douglas and Bennett's Principles and Practice of Infectious Disease, $7^{\text {th }}$ ed. Philadelphia: Churchill Livingstone; 2010. p. 957-85.

8. Akata F. Üriner sistem infeksiyonlarında uygun antibiyotik kullanımı. Klimik Journal. 2001;14(3):114-23. (in Turkish)

9. Clinical and Laboratory Standards Institute. Performance Standards for Antimicrobial Susceptibility Testing; TwentySecond Informational Supplement. CLSI document M100S22. Available at: http://antimicrobianos.com.ar/ATB/wpcontent/uploads/2012/11/M100S22E.pdf

10. Howes DS, Bogner MP. Urinary tract infections and hematuria. In: Tintinalli's Emergency Medicine, A Comprehensive Study Guide: $7^{\text {th }}$ ed. McGraw Hill 2011; p 630-40.

11. Ban MK, Easter JS. Selected urologic problems. In: Rosen's Emergency Medicine, Concepts and Clinical Practice. $7^{\text {th }}$ ed. Marx, Hockberger, Walls, editors. Mosby, Philadephia; 2010: p 1297-324.

12. Çetin M, Ocak S, Görür S, Avunduk G. Semptomatik üriner sistem infeksiyonlarında üropatojenler ve izole edilen $E s-$ cherichia coli suşlarının antibiyotik duyarlılığı. Ankem Derg. 2006;20(3):169-72. (in Turkish)

13. Hooton TM, Scholes D, Gupta K, Stapleton AE, Roberts PL, Stamm WE. Amoxicillin-clavulanate vs ciprofloxacin for the treatment of uncomplicated cystitis in women: a randomized trial. JAMA. 2005;293(8):949-55.

14. Pullukçu H, Taşbakan MI, Aydemir S, Sipahi OR, Turhan A, Özinel MA, et al. İdrar kültürlerinden soyutlanan bakteriler ve çeşitli antibiyotiklere in-vitro duyarlılıklarının değerlendirilmesi. Ankem Derg. 2006;20(1):26-30. (in Turkish)

15. Kamenski G, Wagner G, Zehetmayer S, Fink W, Spiegel W, Hoffmann K. Antibacterial resistances in uncomplicated urinary tract infections in women: ECO.SENS II data from pri- mary health care in Austria. BMC Infect Dis. 2012;12:222. doi: 10.1186/1471-2334-12-222.

16. Yuluğkural Z, Mutlu B. Susceptibility of Escherichia coli strains isolated from urine cultures to some commonly used antibacterial agents. Balkan Med J. 2007;24(1):6-11.

17. Guneysel O, Onur O, Erdede M, Denizbasi A. Trimethop$\mathrm{rim} /$ sulfamethoxazole resistance in urinary tract infections. J Emerg Med. 2009;36:338-41. doi: 10.1016/j. jemermed.2007.08.068.

18. Yalçı A, Aydemir H, Pişkin N, Türkyılmaz R. Uropathogens in patients with symptomatic urinary tract infections and antibiotic susceptibility rates. Klimik J. 2008;21(3):112-7.

19. Kavatha D, Giamarellou H, Alexiou Z, Vlachogiannis N, Pentea $S$, et al. Cefpodoxime-proxetil versus trimethoprimsulfamethoxazole for short-term therapy of uncomplicated acute cystitis in women. Antimicrob Agents Chemother. 2003;47(3):897-900.

20. Khawcharoenporn T, Vasoo S, Ward E, Singh K. High rates of quinolone resistance among urinary tract infections in the ED. Am J Emerg Med. 2012;30(1):68-74. doi: 10.1016/j.ajem.2010.09.030.

21. Caterino MJ, Weed GS, Espinola AJ, Camargo AC. National trends in emergency department antibiotic prescribing for elders with urinary tract infection, 1996-2005. Acad Emerg Med. 2009;16(6):500-7. doi: 10.1111/j.1553-2712 .2009.00353.x

22. Aydın DM, Buyukbaba O, Ang O. Susceptibilities of Enterobacteriaceae strains isolated from urinary tract infections to quinolones. Ankem Derg. 1996;10(1):19-23.

23. Şencan I, Sevinç ME. Antimicrobial resistance survey of community-acquired uropathogen Escherichia coli isolates. Klimik J. 2002;15(3):85-8.

24. Sucu N, Boz GA, Bayraktar O, Caylan R, Aydın K, Koksal İ. Üropatojen Escherichia coli Suşlarının Antibiyotik Duyarlılıklarının Yıllar İçerisindeki Değişimi. Klimik Journal 2004;17:128-31. (in Turkish)

25. Savaş L, Güvel S, Turunç T, Savaş N, Arslan H. Toplum Kökenli ve Nozokomiyal Üriner Sistem Enfeksiyonu Etkenleri ve Antibiyotik Duyarlılıklarının Karşılaştırılması. Turkish J Urol. 2003;29(1):95-100. (in Turkish)

26. Kacmaz B, Aksoy A, Sultan N. İdrarörneklerinden izole edilen Escherichia coli izolatlarındaoral antibiyotiklere karşı direncin araştırılması. Turk Hij Den Biyol Derg. 2007;64(1):11-5. (in Turkish)

27. Köken G, Aşık G, Ciftci İH, Cetinkaya Z, Aktepe OC, Yilmazer M. Efficiency of fosfomycin trometamol on Escherichia coli strains from community acquired urinary tract infections. Ankem Derg. 2008;22(1):23-7.

28. Aypak C, Altunsoy A, Düzgün N. Empiric antibiotic therapy in acute uncomplicated urinary tract infections and fluoroquinolone resistance: a prospective observational study. Ann Clin Microbiol Antimicrob. 2009;8:27. doi: 10.1186/14760711-8-27. 
29. Hooton TM, Roberts PL, Stapleton AE. Cefpodoxime vs ciprofloxacin for short-course treatment of acute uncomplicated cystitis. JAMA. 2012;307(6):583-9. doi: 10.1001/ jama.2012.80.

30. Hoşbul T, Özyurt M, Baylan O, Bektöre B, Ardıç N, et al. Escherichia coli nedenli komplike olmamı̧ üriner sistem enfeksiyonlarında fosfomisin trometamolün in vitro etkinliği. Mikrobiyol Bul 2009;43(4):645-9. (in Turkish)

31. Muvunyi CM, Masaisa F, Bayingana C, Mutesa L, Musemakweri A, et al. Decreased susceptibility to commonly used antimicrobial agents in bacterial pathogens isolated from urinary tract infections in Rwanda: need for new antimicrobial guidelines. Am J Trop Med Hyg. 2011;84(6):923-8. doi: 10.4269/ajtmh.2011.11-0057.

32. Knottnerus BJ, Nys S, Ter Riet G, Donker G, Geerlings SE, Stobberingh E. Fosfomycin tromethamine as second agent for the treatment of acute, uncomplicated urinary tract infections in adult female patients in The Netherlands? J Antimicrob Chemother. 2008;62(2):356-9.

33. Tasbakan MI, Pullukcu H, Yamazhan T, Arda B, Ulusoy S. Toplum kökenli üriner sistem infeksiyonlarından soyutlanan Escherıchıa coli suşlarına fosfomisinin in-vitro etkinliğinin diğer antibiyotiklerle karşılaştırılması Ankem Derg. 2004;18(4):216-9. (in Turkish)

34. Ay S, İseri LA, Duman B. İdrar Örneklerinden İzole Edilen Gram Olumsuz Mikroorganizmaların Antibiyotiklere Duyarlılıkları. J Inonu Univ Med Faculty. 2003; 10(2):59-62. (in Turkish)

35. Geçit I, Benli E, Karakoç S, Şahin M, Hoto D. Bölgemizde üriner enfeksiyona yol açan patojenlere karşı gelişen antimikrobiyal direncin değerlendirilmesi. Tıp Araştırmaları Dergisi. 2011;9(2):115-9. (in Turkish)

Sažetak

\title{
OTPORNOST NA TRIMETOPRIM-SULFAMETOKSAZOL I STOPE OSJETLJIVOSTI NA FOSFOMICIN KOD NEKOMPLICIRANIH INFEKCIJA MOKRAĆNOG SUSTAVA - JE LI VRIJEME ZA PROMJENU PREPORUČENIH ANTIMIKROBNIH LIJEKOVA
}

\author{
O. Guneysel, E. Suman i T. Cimilli Ozturk
}

Infekcije mokraćnog sustava (urinary tract infection, UTI) spadaju među najčešće bakterijske infekcije u odrasle populacije, a učestale su u svim dobnim skupinama i u oba spola. Isto tako, UTI su najčešća indikacija za empirijsko liječenje antibioticima u hitnoj službi. Cilj ovoga istraživanja bio je utvrditi stope otpornosti na antibiotike u liječenju nekomplicirane UTI. U ovo poprečno ispitivanje bili su uključeni odrasli bolesnici primljeni na hitni odjel s nekompliciranom UTI. Uzorci srednjeg mlaza mokraće uzeti su pod sterilnim uvjetima i kvantitativno kultivirani. Nakon 24 sata uzorci koji su pokazivali $10^{5} \mathrm{CFU} / \mathrm{mL}$ testirani su na osjetljivost na antibiotike. Otpornost na fosfomicin-trometamol (FT), amoksicilin-klavulansku kiselinu (AC), ciprofloksacin (CIP), trimetoprim-sulfametoksazol (TMP-SMX) i cefpodoksim (CEF) ispitana je pomoću Kirby-Bauerova sustava disk difuzije. Većinu organizama izoliranih u ovom istraživanju činila je Escherichia (E.) coli $(93,4 \%)$. Među bolesnicima pozitivnim na $E$. coli najčešća je bila otpornost na TMP-SMX. Vrste $E$. coli otkrivene u ovoj skupini bolesnika pokazale su najmanju otpornost na FT (2,4\%). Stope antibiotske otpornosti, poglavito na CEF, AC i CIP, bile su značajno više u bolesnika starijih od 50 godina. Zaključuje se kako bi u liječenju nekomplicirane UTI trebalo iz empirijskog liječenja isključiti TMP-SMX, dok bi fosfomicin mogao biti koristan u svim dobnim skupinama.

Ključne riječi: Urinarne infekcije - farmakoterapija; Lijekovi, rezistencija, bakterijska; Fosfomicin - terapijska primjena; Trimetoprim, sulfametoksazol kombinacija lijeka - terapijska primjena; Hitna stanja 